\title{
DE LA CORTE TROVADORESCA A LA URBE DE LAS MARAVILLAS: LA CIUDAD EN EL TEATRO DE EMILIA PARDO BAZÁN ${ }^{1}$
}

\author{
Montserrat RIBAO PEREIRA \\ Universidad de Vigo
}

\section{RESUMEN}

En la mayoría de las piezas publicadas por Emilia Pardo Bazán y en los fragmentos más significativos de las que han llegado manuscritas hasta nosotros puede rastrarse una constante disociación del espacio en dos ejes en torno a los que gira el conflicto dramático. La urbe (metrópoli, gran capital o de provincias) es el espacio en que triunfa la apariencia, la vulgaridad, el lujo ostentoso y el poder absoluto del dinero, frente al que se sitúa, teatralmente hablando, la tierra de origen, la reserva regeneracional que, metafóricamente, representa al espíritu de las tradiciones en el que Pardo Bazán insiste en profundizar.

Palabras Clave: Ciudad, Teatro, Emilia Pardo Bazán, Fin de Siglo

\section{ABSTRACT}

In most of the pieces published by Emilia Pardo Bazán and the most significant fragments of manuscripts that have come down to us can be a dissociation constant of the space in two axes around which revolves the dramatic conflict. The city (metropolis, capital or provinces) is the space in which triumphs appearance, vulgarity, ostentatious luxury and absolute power of money, against which lies the land of origin, the reserve regeneracional, metaphorically, represents the spirit of the traditions in which Pardo Bazan deepens.

Key Words: City, Theater, Pardo Bazán, End of the Century

1. Este trabajo se inscribe en el Proyecto de Investigación INCITE09-104-249PR, financiado por la Dirección Xeral de Investigación, Desenvolvemento e Innovación de la Xunta de Galicia. 
Los textos teatrales publicados por Emilia Pardo Bazán no son, en lo concerniente al planteamiento urbano de buena parte de sus tramas, una excepción en el conjunto de su obra. Sin embargo, el acceso desde hace ya algunos años a diferentes textos que la autora decidió no dar a la imprenta y que han llegado hasta nosotros de forma manuscrita, por lo general, y fragmentaria (García Castañeda, 1997; Patiño Eirín, 1999; Ribao Pereira, 2010; Thion Soriano-Mollá, 2003), permite retrotraer y ampliar los límites de la constante y pertinente oposición que, de modo formalmente diverso, se establece en todos ellos entre la ciudad a la que llegan los personajes en la prehistoria de la acción y su espacio de origen. Desde sus inicios como dramaturga, doña Emilia esboza esta línea de fuerza que irá cobrando entidad y relevancia a medida que avanza en esta vertiente de su creación literaria, tal y como pretendo abordar en las páginas que siguen.

La ciudad medieval es el contexto en que se desarrolla tanto Tempestad de invierno, cuya acción transcurre en el palacio real de Estocolmo en el siglo XIII, como Los peregrinos ${ }^{2}$. Esta última sitúa el planteamiento de la acción en las cortes de Agen, en un castillo provenzal en el que se trova y donde la hija de los señores, Margarida, es incluso «muy aficionada a la poesía y algo juglaresa» (p. 591). Los protagonistas emprenden el camino de Santiago como penitencia por sus pecados y el desenlace se plantea en las inmediaciones de la ciudad del Apóstol, concretamente en lo alto del Humilladoiro desde el que se divisan las torres de la catedral. La silueta de las mismas, reiterada, como veremos, en el teatro de doña Emilia, cobija a los personajes y proyecta sobre ellos la paz que han buscado durante su peregrinaje, tanto desde el punto de vista social como moral: el perdón para Rambaldo, que no había evitado la muerte de su gemelo porque deseaba a la esposa de este, el convento para Laureta, la viuda, y la protección para los amores de la noble Margarida y el siervo que ha conocido en el camino.

También medieval es la ambientación de El Mariscal Pedro Pardo, drama en el que se verifica ya la rentable oposición a la que antes me refería, en este caso en torno a la ciudad de Mondoñedo y al castillo de la Frouseira. La fortaleza es el símbolo de lo que Pardo representa en su lucha por la legitimidad de la reina Juana frente a Isabel de Castilla: «la independencia de su patria y la conservación de los fueros de la nobleza, a que atentan los Reyes Católicos» (p. 415). De hecho, dos de los tres actos de la pieza (el planteamiento del conflicto y el desarrollo dramático del mismo) se desarrollan en diferentes

2. A propósito de este y los demás textos pardobazanianos a los que me refiero, véase el estudio y la edición Teatro completo (Ribao 2010a), por la que cito en adelante. 
puntos de la plaza del Mariscal y solo el tercero en Mondoñedo. Este es, por oposición y contraste con el anterior, el espacio de la derrota, el de la exposición pública de la traición a que ha sido vilmente sometido el protagonista, el lugar asimismo de la subversión romántica, del triunfo del sino sobre la voluntad del héroe.

Pedro lamenta el alejamiento de la corte en que vive su hija. Aurea, sin embargo, no añora los fastos urbanos, ni siquiera una vida placentera: la hija del proscrito es feliz al lado de los suyos, en su solar, hundidas sus raíces en la tierra por cuya libertad apuestan la vida:
¿Por qué corte, o qué imperio de la tierra
trocara yo la gloria bendecida
de deberte el aliento de esta vida?
¡Oh! ¡Vengan las mujeres más felices,
y desde el caro solio de tus brazos
y besando estas canas tan hermosas
sujeta en tales lazos,
yo las quiero retar a ser dichosas! (p. 430).

De hecho, la humillación de Pardo que Castilla exige para perdonarle la vida no pasa solo por abandonar sus fortalezas y renegar de la reina Juana, sino -acaso la mayor afrenta tal y como se plantea en el texto- por partir hacia la corte ( ¡Tú, cortesano! ¡Tú, traidor!», p. 439). El Mariscal sabe que su causa está perdida, que el tiempo del honor ha pasado y que la nueva sociedad emergente de la crisis del siglo XIV (en paralelo a la revolución burguesa del XIX) ofrece brillo y esplendor a cambio del olvido de las raíces. El ardoroso alegato del héroe romántico, que conoce de antemano lo infructuoso de su lucha, sintetiza algunos de los aspectos a que se asocia esta alabanza de aldea constante en buena parte de la producción teatral pardobazaniana desde sus inicios:

Tiempo vendrá que el noble ya no ciña

la cota y el arnés, ni empuñe lanza, y solo envuelva en sedas y brocados su carne sin vigor, afeminada:

¡tiempo en que sus castillos no el alerta se escuche, ni vigile la atalaya, y solo cante el búho en sus ruinas, al través de las hiedras, y las zarzas! Entonces, en las cortes corrompidas, olvidando los timbres de su raza, irán a doblegar la altiva frente al último capricho del monarca, ¡y verán con asombro que ser pueda progenie del león, la oveja mansa! Yo al menos dormiré mi último sueño 
al dulce abrigo de natal montaña,

junto al caro solar de mi familia,

con mi Dios, con mis gentes, con mi patria.

Soy el último noble (p. 441).

Inverso es el sentido que adquiere la ciudad en el planteamiento dramático de La malinche, vertebrado por la oposición espacial ciudad natal/campamento invasor. La urbe es Cholula, en tiempos de Cortés, representada por su plaza y calles adyacentes, con la gran pirámide al fondo. La vuelta de doña Marina a la ciudad y su ascenso por la escalinata del templo, para adorar de nuevo a la Estrella de la Mañana, es interpretado por sus paisanos como un signo de arrepentimiento y de reencuentro con sus orígenes, con su patria, con sus lealtades otrora olvidadas. Cholula será, según plantean sus habitantes, una trampa mortal para los castellanos, pero la nueva traición de la Malinche la convertirá, en realidad, en la sepultura de los nativos, de sus congéneres. La destrucción de la ciudad es un trasunto no solo del fin de una civilización y del surgimiento de un nuevo orden, sino de la muerte moral de la protagonista, maldita por los suyos como responsable de la tragedia: «Y mientras a lo lejos se oyen gritos de muerte y corre la gente despavorida, la Malinche llora amargamente viendo caer la pirámide» (p. 599).

Urbano se concibe también el espacio en que se desarrollan Un drama, Los señores de Morcuende y las escenas conservadas de Soleá, textos todos ellos custodiados entre los materiales autógrafos del fondo pardobazaniano de la Real Academia Galega. Resulta significativo comprobar cómo en el último de ellos, acaso el que de modo más fragmentario ha llegado hasta nosotros, aun cuando no lleguemos a conocer el nombre de la ciudad en que se ubican los hechos, esta aparece perfectamente definida como esa urbe de las maravillas en que tendrán lugar, al menos parcialmente, la mayoría de los dramas sí publicados por la dramaturga. El ámbito de Soleá es propicio para la ostentación y la apariencia. Los protagonistas, una familia sin ingresos económicos de origen conocido y sin otras armas para sobrevivir que la propia picaresca, se esfuerzan en adaptar su modo de vida a lo que la sociedad acomodada de su tiempo determina como buen gusto. De ahí que la madre considere disparatado que su hijo trabaje ( «iTrabajar! No parece sino que Fredito sea algún holgazán», p. 586) o que mantengan un servicio doméstico que no pueden pagar. La perspectiva de un matrimonio ventajoso para los vástagos de la familia despierta en doña María ciertos remordimientos a la hora de mentir con respecto a su verdadera condición:

Porque su novia es rica me gustaría que supiese, al formalizar las relaciones, que nosotros no lo somos, que cubrimos con gran trabajo las apariencias del 
dinero; que todo aquí es a fuerza de discurrir y de exprimirle el último jugo a una peseta. La verdad. Eso no es deshonra (p. 589).

Sin embargo, la aparición de Fredito en escena devuelve a las tablas los modos urbanos que presuntamente critica la pieza, tal y como ocurre también en otros títulos a los que más adelante me referiré. La exagerada afectación en su vestir y la pedantería en el habla son algunos de los signos teatrales de que se vale el texto literario para subrayar la ridiculez de sus pretensiones:

¿Hay flores para el centro de la mesa? ¿Han traído vinos, por lo menos un borgoña, un clarete para el pescado, un champagne? El criado que ha de servir, ¿tiene frac y pechera tiesa? ¿Tridentes para las ostras? [...] ¿Qué mantelería pondréis? ¿Has pensado en ramitos para el pecho de las señoras y para nuestras boutonières? ¿Hay algún plato de foie-gras? ¿La sopa es demi crème royale o nos vais a dar fideo, como en las casas de huéspedes? (p. 590).

La gran ciudad que aparecerá como telón de fondo en los textos teatrales de ambientación contemporánea publicados por doña Emilia será esta misma urbe en crisis de finales del siglo XIX, industrial y moderna (Vilei, 2010), materialista, burguesa, adocenada en lo espiritual, víctima de unos fuertes convencionalismos de clase e hipócrita en su comportamiento social. Frente a ella, el pazo rural -o la pequeña ciudad, en su defecto- conservará los valores que la urbe menosprecia y se convertirá en la reserva última del honor familiar y de la verdad.

Tal es así, que las piezas en las que no se establece esta dicotomía gran ciudad/pequeña ciudad-campo plantean, efectivamente, desenlaces sin esperanza de mejora futura. Un buen ejemplo es el monólogo El vestido de boda ${ }^{3}$. La historia de Paula Castañar se desarrolla en Madrid, de la que se menciona el propio teatro Lara en que se estrena la pieza, el taller de costura de la calle de la Montera, el convento en que ha sido educada su hija, la casa de vecindad familiar, el hotelito que es ahora su residencia... Tanto el origen como las relaciones sociales de Paula y su familia se circunscriben a este ámbito urbano, del que la modista conoce perfectamente sus engranajes funcionales. De hecho, el conflicto dramático mismo surge del aprovechamiento, en beneficio propio, que la protagonista lleva a cabo de su espacio vital. Tras el episodio con el senador, el encontronazo en la escalera con la oficiala determina su futuro; el ritmo vivo que imprime Paula a sus palabras refleja su inteligente asunción de los hechos:

3. Fue escrito expresamente para la actriz Balbina Valverde y se estrena el 1 de febrero de 1898 en el Teatro Lara de Madrid. 
Salgo de allí, que se podía encender un fósforo en mis carrillos... En la escalera tropiezo con una oficiala de modista, que subía un lío de obra en un pañolón. Inspiración fulminante... «Lío por lío, vengan estos» (p. 82).

A partir de aquí, el anonimato que favorece la gran ciudad auspiciará las sucesivas transformaciones de Paula, que pasará de muchacha rica y desocupada a aprendiza en un taller, para finalmente crear una identidad falsa y mantener una doble vida. Los usos sociales de la capital le permitirán, asimismo, sacar adelante un floreciente negocio, que se sustentará en la necesidad burguesa de exteriorizar sus marcas -tanto reales como ficticias, eso sí- distintivas de clase. Los trajes de soirée, los deshabillé, las robes et costumes que la moda parisina impone en Madrid son el medio del que Palmyre Lacastagne se vale para progresar económicamente y buscar un porvenir provechoso para su hija 4 :

El imperio de las apariencias en el medio urbano favorece, en este sentido, la proliferación de una variante decimonónica del pícaro clásico. La autobiografía (más ficcionalizada que ficticia) de la que da cuenta Paula en su monólogo, el carácter marginal (en lo económico) de la protagonista ${ }^{5}$, las astucias que le permiten medrar, el aprendizaje y posterior independencia de diferentes amos (del senador tras la bofetada, primero; del marido, «un pillo redomado», después), el propio texto como respuesta al interrogante que plantea la ascensión social de la protagonista... son algunas de las deudas de El vestido de boda con la picaresca. En consonancia con todo ello, el desenlace de la pieza ilustra no tanto la culminación de ese proceso de mejora de que ha dado cuenta Paula a lo largo de la misma, sino la trascendencia de las renuncias que ha debido afrontar para llegar a ese punto. La relegación de la propia entidad, el sacrificio de su yo en aras de un bien superior esconden, en realidad, la paradoja de devolver a su hija -el fin último de sus anhelos-al ámbito social, falaz e hipócrita de cuya influencia ella misma había conseguido distanciarse irónicamente a través de la burla y del engaño. Los convencionalismos de la burguesía y la aristocracia madrileñas, de las que Palmyre ha sabido obtener un beneficio personal, engullen a la joven en esas mismas

4. «Pero lo cierto es que antes veía yo el color del dinero de ciertas tramposas que el médico o el panadero... o el maestro de los niños. ¡Hay cada historia en Madrid...!» (p. 85).

5. La muerte del padre sume a la muchacha y a su familia en la pobreza. El episodio con el senador, al que antes me he referido, remite -incluso lingüísticamente- al Lazarillo: «Había cierto señor senador que visitaba mucho nuestra casa... [...] Pues cátate que mi madre, enferma, necesitada, tuvo que pedirle por amor de Dios una pequeñez...» (p. 82). Más adelante, la propia Paula no duda en visitar a todos los que han dejado de ser sus amigos con el fin de pedir prestado el dinero que necesita para poner en marcha su negocio. 
servidumbres, convirtiendo así la telaraña que la ávida modista ha tejido durante toda su vida ${ }^{6}$ en una paradójica trampa mortal: el «ventajoso matrimonio» de la señorita con un diputado de gran porvenir acaso no sea ni tan feliz ni tan prometedor como cabría esperar, y Paula lo sabe ${ }^{7}$.

La ciudad desaparece del segundo estreno pardobazaniano, el diálogo dramático La suerte ${ }^{8}$, ambientado «en un paraje montuoso y quebrado, a las márgenes del río Sil» (p. 90). La vila, que apenas si se menciona, es el lugar en que Payo debe vender el oro de Na Bárbara para librarse de la leva y al que no llegará nunca. Pese a la evidente asociación de lo urbano con lo pecuniario, la acción dramática de la pieza no se sustenta en esta recurrencia, sino que orbita en torno a la fatal relación de los personajes con su entorno natural y a la presencia constante de una «negra suerte» que les persigue.

Bien diferente es el caso de Verdad ${ }^{9}$, título en el que comienza a manifestarse la pertinencia de la oposición entre la ciudad y el solar familiar (rastreable ya en los manuscritos a los que me he referido) en el teatro publicado por doña Emilia. Los hechos se desarrollan en una casa antigua a orillas del Miño, en la frontera con Portugal. Se trata de una vivienda de campo, propiedad de los Trava, cuya decadencia material alude gráficamente al desmoronamiento moral del protagonista, que la habita, y a su concepción del honor, muy diferente de la de su amante, Irene, buena conocedora esta del gran mundo de los salones de Lisboa. El ámbito del protagonista es el de los «borrosos blasones» que adornan el portón de su casa (p. 111), que justifican por sí solos el comportamiento caballeroso de quien ha nacido noble. El de la mujer, sin embargo, es el de la «tiranía del mundo», el de un «círculo vanidoso» (ídem) y exclusivo de curiosos y aduladores ${ }^{10}$.

6. En sus «Crónicas de Madrid» para La Nación escribirá doña Emilia a propósito de estas pretendidas modistas francesas, a las que relaciona con las arañas: «El insecto voraz que para cazar no tiene más arma que un poco de tela transparente, lo identifico con la modista, que quieta en su hotel, aguarda a las señoras que acuden, como el toro, al trapo» (publicado en La Nación, de Buenos Aires, el domigo 8 de diciembre de 1912; cito por Julia Sinovas Maté, Emilia Pardo Bazán. La obra periodística completa en La Nación de Buenos Aires (1879-1921), A Coruña. Diputación Provincial, 1999, pp. 722-726, aquí p. 722).

7. «Lo único nuevo que habrá aquí será que, al ponerse la novia su ideal vestido, no sospechará que entre las perlas que lo recaman puede haberse cajado una lagrimita mía... de gozo... y también de miedo..., porque las bodas asustan... ¡Pueden traer cola! ¿ Si a la chiquilla le saliese como a mí? ¡No quiero ni pensarlo» (pp. 86-87).

8. Se estrena el 5 de marzo de 1904, en el Teatro de la Princesa, en Madrid, y en mayo del año siguiente en A Coruña.

9. Drama en cuatro actos estrenado en el Teatro Español el 9 de enero de 1906.

10. «MARTín: Tú no has querido que yo frecuentase... IRENE: ¡Ni quiero! Nos conocimos... ¿te acuerdas?, aquí, en casa de mis tías, las Vizcondesas de Ourente..., en una fiesta de 
En este contexto, la ciudad aparece en el acto primero del drama como metáfora de la propia Irene, de su hedonismo y de la falta de escrúpulos que la lleva a disfrutar de la vida como si de un juego sin consecuencias se tratase. Para la mujer no existen ni el pasado ni el futuro, solo los breves instantes del presente. Afirmaciones como «Martín, ¿qué más pides? Estoy contigo... Tenemos una horas de dicha...» (p. 116), «¡Martín mío..., estás echando a perder esta hora, única que poseemos, con discordias y exigencias!» (ídem) o «Vamos, no me acibares esta corta noche de verano, Martín» (p. 117), dan cuenta de la inmediatez del sentimiento en la protagonista, de la ausencia de conciencia temporal al respecto, de la superficialidad de sus actos. Su vida pública en la gran ciudad, los bailes a los que asiste, la platea desde la que se deja admirar, su posición como esposa de un relevante político y diplomático... nada tienen que ver con la necesidad de compromiso que expresa reiteradamente Martín, con el inmovilismo de su condición vital, que encarna su casa:

MARTín: [...] Te doy mi vida, te pido la tuya. Soy huérfano, nada me liga. Venderé mi hacienda, hasta este Pazo en que nací, en que residieron mis padres, hasta los muebles de estas habitaciones, que eran las suyas. [...] Iremos a donde nadie nos conozca..., donde nadie te conozca, porque a mí, oscuro provinciano, nadie me conoce fuera de este rincón... [...] Mentiste al pronunciar la palabra amor.

IRENE: No, no he mentido... Pero acaso el amor es... eterno? ¿Lo crees tú? MARTín: Y si tú no lo crees, ¿por qué estás aquí, donde vivió y murió mi madre? (p. 117).

La tradición, la herencia, las costumbres heredadas constituyen para Martín un foco de verdad incompatible con la hipocresía de la ciudad. Por eso ha querido encontrarse a solas con su amante en su solar, lejos de las intrigas urbanas. Irene no saldrá nunca de Trava, pero la ciudad volverá para reclamar su memoria en el último acto, cuando el conde de Portalegre rompa su silencio de años y acuda al campo con la amenza de hacer público, en Lisboa, el final trágico de la mujer si Martín no confiesa el crimen. La búsqueda ibseniana de la verdad a ultranza, materializada en el pazo, acabará por socavar sus cimientos, pero seguirá siendo la marca que distinga, aun en la desgracia, el espacio del honor del de la maledicencia ${ }^{11}$.

labradores... MARTín: Desde aquel día mi vida cambió....IRENE: Me seguiste a Lisboa... Te prohibí que penetrases en mi círculo... Ni era fácil, de todos modos, porque no les gustan las caras nuevas...» (p. 111).

11. La consideración social sigue siendo el resorte que mueve la acción de los personajes que proceden de la ciudad, de Lisboa en este caso. Irene había tramado el engaño del adorador para desviar la atención hacia Portalegre en caso de suspicacias. En el desenlace es este último quien, tras seis años de silencio y de ausencia, vuelve a la capital lusa 
En Juventud la oposición significativa al solar patrio se establece con la pequeña ciudad de provincias, que no se nombra explícitamente, pero en la que fácilmente se descubre Santiago de Compostela (Ribao, 2010b). Ya la acotación inicial prescribe en el decorado la presencia, en perspectiva, de las «torres de una Catedral», cuya sombra preside el devenir de los hechos dramatizados y cuyo valor simbólico es evidente. La historia, la tradición y los poderes preestablecidos se dan la mano en una urbe organizada en torno a la Iglesia y a la Universidad, los dos establecimientos que determinan el presente y el futuro de los protagonistas. En efecto, la herencia de Bernardo procede de la generosidad del Deán, quien en su testamento ha supeditado la percepción de lo estipulado al hecho de que el joven termine sus estudios universitarios. Inés, por su parte, será apartada por su propio círculo social en nombre de una religión contra la que atenta manteniendo relaciones con Sálvora.

Compostela aparece perfilada en el texto como una ciudad de otra época, suspendida en el tiempo. De su configuración arquitectónica se destaca el Pórtico de la Gloria y sus «profetas bobos» (p. 303), así como el monasterio de santa María de Conxo fundado por el arzobispo Gelmírez (p. 305). De su geografía humana se mencionan las idas y venidas del señor Magistral, cuyas sobrepellices lava y plancha Misia Fidela para ganarse el sustento (p. 305), los vaivenes políticos y la alternancia de partidos (p. 316), los rurmores que circulan en los círculos sociales distinguidos (p. 317), o las charlas domésticas de «los señores catedráticos» (p. 306), inmersos en una serie de revueltas en las que puden entreverse ecos de la cuestión universitaria a la que se enfrentan las Academias en los años sesenta y setenta del siglo XIX.

Bernardo de Sálvora contesta a este ordenamiento social compostelano enfrentándose a sus poderes fácticos: desprecia el legado del Deán y vuelve en su contra a la jerarquía académica, todo ello en nombre de una individualidad a ultranza que reivindica como filosofía de vida. El conflicto dramático no surge, sin embargo, de esta conciencia asocial del protagonista, sino de la quiebra de su heterodoxia vital tras la irrupción en escena de la conciencia nobiliaria encarnada en Jacobo de Montemor. El hermano de Inés llega a la ciudad desde su solar de origen y rápidamente se postula como representante de un modo de vida alternativo, ligado a valores primarios: familia, tierra... y bienestar económico ${ }^{12}$. Las altas tapias que rodean el jardín de Inés y de

y se decide a hablar, ya que «En Lisboa se me han hecho desaires crueles; se me acoge con sospecha, con frío desdén... No es justo; no hay motivo para que prolongue una abnegación tan funesta para mí» (p. 153).

12. «JАСОВО: Ya sabe usted lo que sucede: se mete uno en la aldea; se embelesa con la familia; empieza uno a cuidar los cuatro ferrados de tierra que posee; se desacostumbra 
Bernardo, y que les aislan de la realidad compostelana circundante, dejan de protegerles cuando se establece el contraste con Montemor. Jacobo, al verbalizar ese espacio no solo físico, sino también metafórico, que actúa como una zona de la conciencia (Filgueira Ganzo, 2002: 82), recuerda a la protagonista los deberes ligados a su apellido, la necesidad de mostrar una firme apariencia de honorabilidad y de merecer el respeto público. La burbuja en la que se ha recluido para vivir su amor asocial con Sálvora estalla al contacto con la realidad de sus orígenes, de ahí su desesperada necesidad de huir en busca de sí misma:

INÉS. (Rompiendo a llorar nerviosamente). ¡Sácame de aquí, hermano! ¡De esta casa, de este jardín, de este pueblo!

JАСОво. (Bajo). A Montemor... Esta misma tarde (p. 328).

El regreso de Inés a Santiago en el tercer acto deriva de la claudicación de sus deberes en favor de sus instintos amorosos. El retorno coincide con la rendición intelectual de Bernardo, quien abandona su jardín para sumergirse en las convenciones urbanas de las que abjuraba al inicio de la pieza. La muerte del auténtico Sálvora se emparenta con la asunción de las normas de la pequeña ciudad en que vive ${ }^{13}$. En este contexto deja de tener sentido su antigua pasión por Inés, ideal y subversiva. Privado de libertad, inmerso por voluntad propia en la marea social que, en adelante, decidirá por él, la relación convencional que la joven le ofrece tras su repentina y momentánea vuelta de Montemor carece ya de interés alguno para Bernardo. La protagonista retorna definitivamente al campo, como tenía previsto (p. 340).

Que el solar de una casa noble es la fuente de la que acaso pueda surgir una alternativa a la pérdida de los valores tradicionales y conservadores encarnada por la ciudad es una de las claves de lectura de Cuesta abajo ${ }^{14}$. De hecho, desde el inicio de la obra se establece una comparación constante entre aquí (Madrid) y allá (la aldea de Castro Real) de enorme rentabilidad dramática. En la urbe, el Casino, las veladas aristocráticas, las cacerías, la Bolsa y los

de venir al pueblo... y el día en que se ve precisado, un sacrificio. CATEDrático: [...] Te conviene dar tus vueltas, hasta por la política, que la tienes abandonada. Cuando vuelvan los nuestros... JАСОВо: ¡Ah! Entonces... Eso le saca a uno de sus casillas. Tendré que irme por ahí de Poncio, sabe Dios a qué ínsula, como ya una vez me sucedió. En la oposición, al menos, descansamos y se hacen economías» (pp. 315-316).

13. «Ahora se va a ver quién es Bernardo Sálvora, sesudo, observador de la realidad y también explotador de ella, ¡qué diantre! Ahora se va a ver lo que un hombre sube por fuera... cuando no le importa bajar por dentro. [...] Y otro soy. [...] Otro Bernardo, activo, práctico, que en breve será piloto en el mar social donde va a engolfarse, es el que te saluda, el que se pone a tus pies» (pp. 342-344).

14. Comedia dramática en cinco actos estrenada en el Gran Teatro el 22 de enero de 1906. 
toros (pp. 175 a 178) tejen una red de relaciones sociales sustentadas en la apariencia, en la ociosidad y en la ausencia de toda moral. Como explica Celina a su abuela, la Condesa, a la llegada de esta,

[...] bien se ve que no conoces el personal, ni el escenario, ni la comedia. Madrina, aquí nadie tiene nada que hacer y nadie tiene tiempo para nada: aquí no se atrapa a nadie como no sea ofreciendo diversión y comida (pp. 184-185).

La Condesa, que voluntariamente se ha retirado de la vida de la capital y disfruta de la soledad de la aldea, encarna una visión de la vida impensable ya en Madrid. Uno de sus principios es la importancia del pasado, de la herencia (material y moral) recibida de la familia, en la que se sustenta-como hemos visto de modo habitual en el teatro parodbazaniano- la honorabilidad de una casa. De ahí que don Venancio no pueda sino dar tratamiento de respeto a Javier, con quien ha bromeado desde niño, cuando este alcanza la edad adulta y se convierte en heredero, o que todo su afán sea ordenar los archivos de la familia para reconstruir su genealogía. En la capital, por el contrario, el respeto por las tradiciones no se entiende ni se da valor a los papeles ${ }^{15}$.

La pertinencia de la concepción de lo temporal, en términos de durabilidad, que expresa la anciana se traduce materialmente en su exigencia de mantener la disposición tradicional de la vivienda («ya sabéis que todo lo quiero invariable», p. 180) y el orden de sus muebles. Celina, como el resto de la familia, achaca al capricho de la protagonista este afán trasnochado, tras el que se esconde, sin embargo, una razón más profunda:

CELINA: Todo lo encontrará usted como si hubiese salido ayer de aquí la madrina. A fuerza de cuidarlos he llegado yo también a tomar cariño a estos muebles, no sé por qué. [...].

CONDESA: Porque te infunden ideas de algo duradero. Eso de estar volviendo todo patas arriba es de ricachones improvisados y caprichosos. Mientras un mueble sirve, ¿A qué renovarlo? (p. 182).

Hasta tal punto vive la Condesa ajena al mundo de sus hijos que el propio Felipe, aun reconociendo la bondad de la madre, la percibe como una extraña. De nuevo el aquí y el allá explican estas divergencias:

CONDE: [...] Ella vive allá, tan fuera del movimiento que nadie se acuerda de que existe... [...] Yo reconozco sus méritos... No puedo quejarme de mi

15. «JAVIER: Apéeme el tratamiento. Hábleme de tú, como entonces. VenANCiO: (Asustado) ¿Ahora, señorito? ¿Al primogénito de la casa? ¡No puede ser! (...) ¡Venga a Castro Real; le enseñaré unas ejecutorias magníficas, que andaban traspapeladas! JAVIER: Si me enseña billetes de banco, voy. ¿Quién piensa en papelotes comidos de las ratas?» (p. 181). 
madre; me ha entregado mi herencia íntegra, sin reservarse nada. Pero ni me entiende ni la entiendo. Si me hubiese quedado cerca de ella, en nuestro solar, qué diferente mi suerte... ¡Bah! ¡Quién piensa en eso! (pp. 174-75).

Frente al mundo de Castro Real, el de la ciudad -tal y como señalan los protagonistas- encarna la frivolidad de las relaciones sociales, el clasismo excluyente, la ausencia de pudor, la impiedad y la falta de dignidad. Así, por ejemplo, para alabar la decoración del nuevo salón de Gerarda la Marquesa de Castel Quemado se ve en la necesidad de criticar el de Gracia Altacruz (p. 187). Sin embargo, para asombro de sus nobles amigas, la Condesa afirma disfrutar en la aldea de la tertulia con sus parroquianos,

[...] que soy más democrática que ustedes y también llamo gente a mis colonos, a los modestos ciudadanos de la villa de Castro Real. Aquí no es gente, por lo visto, sino la que figura (p. 189).

La expresión deíctica de la oposición campo-ciudad sigue manifestando su relevancia en las palabras de la Condesa hasta el final del acto II. Tras la muerte de su hijo menor declara haberse retirado del mundo, incapaz de disfrutar con fiesta alguna, a lo que la Marquesa replica: «si por tales cosas se retrajesen aquí...» (p. 190). Del mismo modo, manifiesta una religiosidad sencilla pero respetuosa de sus normas; a la pregunta sobre si se ha convertido en una beata, responde:

No; lo único que hay es que allí, como se dispone de tiempo, se puede cumplir con un amigo muy elevado, al cual aquí... ni le pagáis las visitas (p. 191).

Esta vivencia absoluta del aquí y del ahora en la ciudad, sin atención al pasado ni conciencia de provenir, se plasma incluso en el aspecto físico de las damas de la alta sociedad coetáneas de la Condesa: mientras la protagonista ha envejecido con el paso de los años, sus antiguas compañeras de juegos no solo no acusan el devenir temporal, sino que han ido rejuveneciendo paulatinamente. Como indica Celina irónicamente,

De cierto, aquí no se vive como vivirá usted allá. [...] Ya no hay muchachas.

Ese género se acabó. En cambio tampoco hay viejas. Todas las mujeres aquí tienen cierta edad: la edad de ser temibles (p. 185).

Con el descubrimiento por parte de la Condesa, en el tercer acto, de la bancarrota familiar, la oposición campo/ciudad se reorienta hacia la caracterización exclusiva del ámbito urbano. Tres son las manifestaciones fundamentales a este respecto, expresadas por representantes de otras tantas generaciones de Castro Real: Celina sintetiza la esencia de la sociedad madrileña, su padre analiza el funcionamiento de la familia en ella y la abuela expone su propuesta de salvación. El paralelismo entre la organización del núcleo privado y del 
público que se deduce de sus palabras pone de manifiesto el origen común de las tensiones que afectan a estos dos ámbitos, así como la coincidencia en la solución que el drama plantea. Así, a las palabras de la muchacha, «Mientras tú rezabas allá, ellos se arruinaban aquí... [...] Madrina... Vas a creer que soy muy mala..., pero te lo aseguro: sin dinero la honra peligra. Esta sociedad respira por el bolsillo» (p. 208) y a las del conde ( «Hoy no hay pilotos. Cada cual rige. Así va la nave», p. 210), la protagonista responde ofreciendo una alternativa de regeneración a partir del retorno a los orígenes: «A Castro Real debíais venir todos» (p. 212).

El cuarto acto repite el mismo esquema del anterior: constatación de los vicios de la capital por parte de los personajes que la habitan y auxilio que procede de la Condesa, ajena física y moralmente a la realidad de su familia. La degradación de las costumbres se expresa aquí de forma extrema, mediante la aparición fugaz -pero significativa- de una actriz francesa, amante a la vez del Conde y de su hijo, al tiempo que pretendida por los amigos de este último. La presencia de la cortesana en el ámbito privado de los Castro, luciendo las joyas que ha robado Javier a su propia abuela, es recibida con entusiasmo por los jóvenes desocupados en los que, paradójicamente, radican todas las esperanzas de la nobleza finisecular ${ }^{16}$. La nueva réplica de la Condesa aúna la reivindicación del honor personal y la del orgullo nobiliario: frente al poder del dinero, la dignidad de los actos de quienes están obligados, por sus orígenes, a servir de modelo social, es la única garantía de salvación ya no solo moral, sino también física:

$[\ldots]$ ¿No nos toman por lo serio esas sociedades nuevas que ofrecen oro por el vino añejo de nuestros nombres? Todo pende de nosotros, de la dignidad de nuestros actos. [...] Vente, hijo mío, salgamos esta misma noche para Castro Real; verás cómo se van de tu cabeza los malos pensamientos... Vente; así... no correrá peligro tu vida (p. 231).

En el final de la pieza se consuma el abandono de la ciudad, bien por huida hacia un paradero desconocido (Conde), por un cambio de vida radical que implica la adopción de una nueva identidad (Celina) o por el retorno al solar de los herederos. La aldea parece plantearse, así, como una variante teatral del cronotopo idílico analizado por Bajtin, al que -en palabras de T. Dorca- retornan, para encontrarse a sí mismos, los conversos del gran mundo, hastiados

16. «JAVIER: Necesitaría poner toda la carne en el asador; porque la Colombe, en este momento, no me hace a mí tan fácilmente una perrería. La tengo muy contenta. Figúrate que se iba a marchar de Madrid; no había venido aquí sino por curiosidad, a comprar mantones y a ver bailar flamenco; en fin, a estudiar las costumbres... GORITO: Las malas costumbres» (p. 221). 
de sus cantos de sirenas (Dorca 2004, 28). Y si bien es verdad que Javier no sobrevive a sus heridas físicas -trasunto de las morales que han arruinado su juventud-, la llegada de Gerarda y su hijo deja abierta una puerta a la esperanza en el desenlace. La limpieza de alma de la mujer enmienda su falta de blasones; el hijo de la plebeya es el único sucesor de la tradición familiar, llamada a renovarse desde sus raíces o a desaparecer ${ }^{17}$.

Madrid, el centro moralmente dañado del país, que dista mucho de ofrecer al resto un ejemplo recomendable (Miller, 1988: 236) se convierte, en Cuesta abajo, en una ciudad de las maravillas donde nada es lo que parece y en la que a todo puede aspirarse si se dispone de los medios materiales necesarios para adquirirlo. Otro tanto puede decirse de Las raíces y de El becerro de metal, aunque con diferentes matices significativos.

La primera de estas dos piezas se ambienta en un hotelito madrileño en el que los Alarcón preparan una fiesta navideña. Las visitas de cumplido, el lujo de los salones, el trato exquisito, los cumplidos en francés que se suceden... son el maquillaje formal de una familia cuyos cimientos, en realidad, se tambalean. El motivo fundamental de la acción dramática no es el sugerido adulterio de Susana con el banquero Casarrobles (del que habría resultado la hija pequeña del matrimonio, Fifí), sino el interés económico que lleva a la mujer a entablar una relación con él. El marido engañado, ajeno a todo ello, cree en la felicidad absoluta; las circunstancias le enseñarán que en la vorágine urbana los sentimientos carecen de valor en sí mismos.

El desengaño de lo afectivo se produce en dos ámbitos, teórico uno de ellos y dolorosamente práctico el segundo. El hermano del protagonista, don Vicente, que acude a Madrid a fin de rescatar su fortuna y encontrar una esposa para su hijo, es el primero en exponer, en términos materiales, las líneas fundamentales que rigen su conducta en ambos sentidos. Tío y sobrino conciben la vida como un combate y una conquista, sus posesiones como «pedazos de carne» que deben defender de la ambición de los demás, y el éxito como una recompensa por sus actos, no por la bondad de sus sentimientos:

Mi hijo, negociante como yo, viene a tratar de encontrar novia... [...], le acompaño en clase de agente de policía, para que, si hace una atrocidad, al menos la haga con pleno conocimiento de los antecedentes, esos antecedentes que no son por completo del dominio público y que jamás llegan hasta los

17. Al hilo del comentario de Claudio Guillén (1989: 116-117) sobre Insolación, podría decirse que este es un drama de Madrid sin protagonistas madrileños. Paradójicamente la salvación de la casa de Castro Real está en manos no solo de la plebeya, sino de la foránea, la única no-gallega de la familia. 
que parten de la suposición de que la gente es buena o quizá mediana. [...] Investigaría tratándose de mi propio hermano (p. 357).

La ceguera de Aurelio le impide dar crédito al tajante positivismo de sus familiares $^{18}$. Serán los hechos protagonizados por su esposa quienes le harán ver la luz. En efecto, Susana comparte la visión combativa de la vida en la ciudad expuesta en el acto I por su cuñado, pero ha creado para su marido una ilusión de armonía en la que este ha adormecido su sentido crítico ${ }^{19}$. En el momento de afrontar la verdad, sus piernas tiemblan (p. 369), pero su voz no desfallece para plantear el chantaje sentimental que le permitirá conservar su matrimonio y la fortuna que ha salvaguardado gracias a la relación con el banquero Casarrobles ${ }^{20}$.

Susana, su cuñado y su sobrino, se identifican con la ciudad en la que habitan y ejemplifican la relación metonímica entre el ambiente y la conducta a la que se ha referido ya E. Penas a propósito de los cuentos pardobazanianos (Penas Varela 2006: 172). Pero a diferencia de lo que ocurría en los dramas que anteriormente he comentado, no existe en Las raíces un solar patrio al que huir y en el que regenerar el honor y la sensatez perdidos en la ciudad, de ahí que el final del drama no ofrezca ningún tipo de esperanza para los protagonistas. La muerte de Fifí ajusta el lazo que la ilusión de felicidad ha anudado en el alma de Aurelio. Desengañado ya, este se condena a sí mismo a vivir una farsa, mientras que Susana paga con la vida de la hija su propia ambición.

También en El becerro de metal la ciudad es el lugar al que se acude a buscar y encontrar una posición de poder. Como en Las raíces, falta en este drama un espacio rural que ofrezca soluciones a los males del alma de los protagonistas, si bien se alude a un ámbito geográfico amplio (Mallorca, sin más precisiones) donde sí es posible aún la felicidad. La huida de Madrid permitirá a la pareja Susana-Torrellas empezar una nueva vida regida por principios bien diferentes de los encarnados por los Leyva.

18. «Hay que dejarte hablar; tú no eres ni tan egoísta ni tan interesado como te finges... ¡Si no te conociésemos!» (p. 356).

19. «Hubiese sido preciso combatir, defender nuestro puesto en el mundo... Tú viviste descuidado, tranquilo... y encantado... No lo niegues... Lo repetías a cada instante, ¡nadie más feliz que tú!» (p. 372).

20. «Piensa con calma las consecuencias de tus acciones y no las realizarás, porque realizarías un crimen. De mí no hablemos; yo no importo. Pero si me obligas a renunciar a mi fortuna la escasez matará a Fifí y dejará a Gracia sin marido, sin establecimiento posible, trabajando para comer, con los dedos picados de la aguja y la cara marcada por las privaciones. ¿Concibes a tu hija sin trajes de seda? ¿Concibes a tu hija subiendo pisos para cobrar tres pesetas? ¿La concibes casándose con un hombre tosco y grosero, que la mantenga y la maltrate?» (pp. 372-373). 
La familia de sefardíes vuelve a España desde París en busca de una fortuna aún mayor de la que atesoran. Su mundo social se circunscribe a un triángulo urbano (Madrid-París-San Sebastián) del que Mallorca (no una ciudad cerrada y acotada, sino un espacio amplio, el de la regeneración ${ }^{21}$ ), alejada de las órbitas aristocráticas del poder, quedará al margen. La capital francesa es el pasado, observado desde dos puntos de vista encarnados por la pareja protagonista. La muchacha rememora los bulevares, las grandes avenidas, las compras y los paseos. Pedro, por su parte, evoca a través del color y la luz parisinos sus anhelos, sus esperanzas amorosas de entonces, sus deseos a propósito de la muchacha, a quien ha seguido sin saber quién era e ignorando que el destino iba a unirles en el Sud-Exprés: "Tres horas detrás de usted, pisando sus huellas... ¡Qué gusto! ¡Cuánto sol, qué luz y qué bonitas estaban las calles de París» (p. 262).

Mallorca aparecerá muy pronto en el discurso de los jóvenes como esperanza de futuro. En ella están las raíces de Torrellas y los orígenes de la familia Leyva, circunstancia que la eleva a categoría de símbolo. Desde ella se entiende el sentido de las antítesis caracterizadoras que se establecen desde el primer acto: el viejo caserón del muchacho, en oposición al lujo del palacio de los judíos; el gusto por lo heredado frente a la ostentación de lo adquirido; las convenciones de la corte en oposición al anonimato liberador de la pequeña ciudad, definen el espíritu del protagonista por contraste con el de sus antagonistas y le acerca al universo emocional de Susana, a quien le interesa «lo íntimo; lo social muy poco....» (p. 277).

El presente, el tiempo de la acción dramatizada, se desarrolla en Madrid. Todos los movimientos de los sefardíes en ella responden a un plan perfectamente orquestado: la amistad con el marqués de Neblí, que les abrirá las puertas del gran mundo, «al objeto de que nos informe y nos ahorre esos primeros desaciertos, que son fatales» (p. 252); la compra de un palacio para fijar en él su residencia; el matrimonio, en fin, de Susana con un grande de España, de modo que los nietos del judío se cubran ante el mismo rey (p. 275). La finalidad última del viejo Simón no es, sin embargo, de tipo emocional. En España no busca ni satisfacciones de orgullo ni venganza de raza, sino poder

21. Significativas son, a este respecto, las palabras de Torrellas en el primer diálogo que mantiene con Susana, aún en el tren camino de la frontera: «Vaya usted, Susana... Cuando se desea una cosa, hacerla enseguida: a lo mejor se atraviesa el destino y la frustra. Yo no dejo nada que me agrade para después... Todo al instante. La vida es corta... Vaya usted a Mallorca, hace más sol que en París. Allí la aguardo. La guío, la enseño los sitios pintorescos, las grutas... ¡Y me envidia el rey...!» (pp. 263-264). 
económico, y la gran ciudad -Madrid ahora, como anteriormente París- es el espacio idóneo para conseguirlo22.

Dos son los modos en que se plantea la conquista de la capital. El primogénito, Ezequiel, propone ganar la confianza, la simpatía y el respeto público de los poderosos haciendo alarde de altruismo, superando incluso al Estado en munificencia:

Yo fundaría en Madrid un establecimiento benéfico modelo, como el Estado no lo ha fundado nunca... Yo regalaría [...] obras de arte a los museos... El Estado español no compra nada, deja que nos lo llevemos todo... Enseñaríamos su deber al Estado... Haríamos algo sensacional... La prensa lo divulgaría... Dominaríamos por la cultura y el bien (p. 255).

La opción de Benjamín, por el contrario, desnuda de apariencia de bondad la actuación de la familia. Como su hermano, desprecia el país y la ciudad en que van a instalarse, pero en su caso propone manifestarlo descarnadamente, sin cuidado por las formas:

Es preferible dominar por la soberbia y el desprecio. Divertir, prestar, humillar, deslumbrar... Es un goce de venganza, exquisito, y lo estoy saboreando ya. ¡Qué de adulaciones, qué de bajezas vamos a paladear cuando entremos en campaña con nuestro oro! ¡Y hasta podemos darnos este placer refinado a poca costa! Madrid es pobre. El lujo allí consiste en un abono a medio turno y un coche con dos rocinantes... (ídem).

El acto II de la pieza muestra hasta qué punto el patriarca Simón ha decidido seguir las inclinaciones de sus dos hijos. La suntuosidad como medida del valor de personas y objetos, la concepción de la cultura (teatro, ópera, museos) como escaparate en que mostrarse y ser vistos, el menosprecio de la pobreza a través de la caridad... son aspectos de la sociedad madrileña que los Leyva conocen y rentabilizan para conseguir sus fines. Ni siquiera la religión es un obstáculo a la hora de acordar el matrimonio de Susana, de ahí que la llegada del Gran Rabino, para impedirlo, no plantee a la familia ningún conflicto de tipo moral, sino un auténtico problema social derivado de la inconveniencia de presentar, ante el gran mundo, a un personaje como él.

En el desenlace, Susana reniega de su fe y abandona a su familia. Ismael cree que el ambiente de la ciudad ha influido negativamente en ella (p. 292) hasta el punto de conducirla al perjurio. Sin embargo, nada más lejos de la realidad: impermeable a los cantos de sirena del espacio que la rodea, la

22. «SIMÓN: [...] España es un terreno virgen, o poco menos, para las especulaciones atrevidas y geniales. He estudiado ese terreno y sé lo que puede rendir... Esto hará el viejo Simón de Leyva antes de ir a dormir al lado de sus padres... Con estos dedos exprimiré la última gota de jugo a la naranja española» (p. 256). 
muchacha ha sucumbido al poder irracional de los sentimientos, la única línea de fuerza ausente en el discurso dramático sobre la urbe que han sostenido los diferentes personajes a lo largo de la obra.

Como puede verse, en términos generales -salvo en los títulos de ambientación exclusicamente rural como La suerte-, en las piezas publicadas por doña Emilia y en los fragmentos más significativos de las que han llegado manuscritas hasta nosotros puede rastrarse una constante disociación del espacio en dos ejes en torno a los que girará el conflicto dramático. En los textos de ambientación medieval la corte es el lugar del crimen, de la traición, del desdoro nobiliario y de la pérdida del honor que conducen bien a la muerte física del Mariscal Pedro Pardo y a la moral del rey Erico, bien a la búsqueda de salvación espiritual en el camino hacia Santiago de Compostela. No hay, sin embargo, en estos fragmentos, una reivindicación idealista de lo patrio, ni siquiera desde la óptica romántica de la estética subyacente a los mismos, sino la identificación de los personajes con su medio, por el que luchan, en el que sucumben o del que huyen.

También en La Malinche la ciudad se tranforma en el ámbito de la deshonra, si bien interpretada de modo diverso en función de la perspectiva (urbana y nativa, de extramuros e invasora) que se adopte. En el resto de los títulos, de ambientación contemporánea, la urbe (metrópoli, gran capital o de provincias) es el espacio sobrevenido en que triunfa la apariencia, la vulgaridad, el lujo ostentoso y el poder absoluto del dinero, frente al que se sitúa, teatralmente hablando, la tierra de origen, la reserva regeneracional que, metafóricamente, representa al espíritu de las tradiciones en el que doña Emilia insiste en profundizar para descubrir «los gérmenes de progreso, de libertad, de tolerancia, de fe, de trabajo y de esfuerzo viril ${ }^{23}$.

\section{BIBLIOGRAFÍA}

DORCA, Toni. Volverás a la región. El cronotopo idílico en la novela española del siglo XIX, Madrid, Iberoamericana-Vervuert, 2004.

FILGUEIRA GANZO, Jesús.«Observaciones sobre el espacio en Insolación de Emilia Pardo Bazán», Moenia, 8 (2002), pp. 79-102.

GarCía CASTAÑEDA, Salvador. «El teatro de Emilia Pardo Bazán: estado de la cuestión», en José Manuel González HerRÁn, ed., Estudios sobre Emilia Pardo

23. Tomo estas palabras, que proceden de la conferencia La España de ayer y la de hoy: la muerte de una leyenda, pronunciada por E. Pardo Bazán en París (1899), del estudio de M. Sotelo sobre la misma (1999: 362). 
Bazán in memoriam Maurice Hemingway, Santiago, Universidad de Santiago de Compostela, Consorcio de Santiago, 1997, pp. 113-145.

Guillén, Claudio. «Entre la distancia y la ironía: de Los Pazos de Ulloa a Insolación», en Marina MAYORAL, ed., Estudios sobre Los Pazos de Ulloa, Madrid, Cátdra, Ministerio de Cultura, 1989, pp. 103-128. Reeditado en Claudio GuILLÉN, 2006. «Pardo Bazán. De la distancia a la ironía», De leyendas y lecciones. Siglos XIX, XX, XXI, Barcelona, Crítica, pp. 65-88.

MACKEVITT, Kerry Ann. «O espazo simbólico: Pardo Bazán, Valle-Inclán e os pazos galegos señoriais», Bradomín, 1 (2005), pp. 67-77.

MiLler, Stephen. «Madrid y la problemática regionalista en Pereda y Galdós», Boletín de la Biblioteca de Menéndez Pelayo, LXIV (1988), pp. 223-251.

PATIÑo EIRín, Cristina. «La experiencia frustrada en el teatro: Un drama, inédito textual y teatral de Emilia Pardo Bazán», Siglo Diecinueve (Literatura Hispánica) 5 (1999), pp. 93-15.

Penas VARela, Ermitas. «El espacio en los cuentos de Emilia Pardo Bazán: una aproximación», en José Manuel GonZález Herrán, Cristina PatiÑo EIRÍN y Ermitas Penas VArela, eds., Actas II Simposio Emilia Pardo Bazán: Los cuentos, A Coruña, Real Academia Galega y Fundación Caixagalicia, 2006, pp. 153-174.

Ribao Pereira, Montserrat. E. Pardo Bazán, Teatro completo, Madrid, Akal, 2010a.

RiBAO PEREIRA, Montserrat. «Un ejercicio de autoafirmación estilística: los manuscritos teatrales del drama Juventud, de Emilia Pardo Bazán», en Raquel GutiérRez SEbAstián et al., eds., Desde la Platea. Estudios sobre el teatro decimonónico, Santander, Universidad de Cantabria, 2010b, pp. 191-208.

SANTISO, Julia. «Breve aproximación a los espacios creativos de Emilia Pardo Bazán», Cuadernos Hispanoamericanos, 669 (2006), pp. 7-23.

Sotelo VÁzQuez, Marisa. «Emilia Pardo Bazán ante la crisis del 98: La España de ayer y la de hoy: la muerte de una leyenda», en A. VILARNOVO et al., eds., La crisis española de fin de siglo y la Generación del 98, Barcelona, Universitat, 1999, pp. 355-368.

Thion SORIANO-Mollá, Dolores. «Et elle leur donna la voix: paroles de femmes dans les commédies dramatiques d'Emilia Pardo Bazán», Paroles de femmes, Nantes, Universidad de Nantes, 2003, pp. 129-151.

VILEI, Leonardo, 2010. «Soledad y solidaridad: la fábrica», en Eugenis PoPEANGA, coord., Ciudad en obras. Metáforas de lo urbano en la literatura y en las artes, Barcelona, Peter Lang, 2010, pp. 255-266.

Fecha de recepción: 20-11-2011

Fecha de aceptación: 15-05-2012 